Journal : JMMR (Jurnal Medicoeticolegal dan Manajemen Rumah Sakit), 10 (1): 1-12, April 2021

Website : http://journal.umy.ac.id/index.php/mrs

DOI : https://doi.org/10.18196/jmmr.v10i1.10296

\title{
Hospital Management Information System Usefulness in The Health Services Industry at Indonesia: Mandatory or Voluntary?
}

\author{
Victor Livinus $^{1}$, M.F. Arrozi Adhikara ${ }^{2}$, Rokiah Kusumapradja ${ }^{3}$ \\ ${ }^{1 *}$ Correspondence Author: v.livinus@gmail.com \\ ${ }^{1}$ Hospital Administration Magister Program Esa Unggul University, Jakarta, Indonesia \\ ${ }^{2}$ Department of Accounting, Faculty of Economic and Business Esa Unggul University, Jakarta, Indonesia \\ ${ }^{3}$ Hospital Administration Magister Program Esa Unggul University, Jakarta, Indonesia

\section{N D E X I N G} \\ Keywords: \\ Perceived Usefulness; \\ Perceived Ease of Use; \\ Computer Self-Efficacy; \\ Behavioral Intention to \\ Use; \\ Actual Technology Use;

\begin{abstract}
A B S T R AC T
This study aiming to obtain empirical evidence of usefulness, ease of use, Computer Self-Efficacy (CSE), and intend to use towards Actual Use of Technology (ATU) as an issue of high complexity of healthcare organizations services. We use causality explanatory research for hypothesis testing with quantitative approach as methods. Data were analyzed by Path Analysis. Result: Perceived Usefulness (PU) had positive effect on Behavioral Intention to Use (BITU). Perceive Ease of Use (PEOU) had significant positive effect on ATU. Conclusion: BITU is an intervening variable that can mediate the effect of PU toward ATU. These findings suggested that there is mandatory behavior toward users to apply SIMRS.
\end{abstract}

\section{Kata Kunci:}

Perceived Usefulness; Perceived Ease of Use Computer Self-Efficacy; Behavioral Intention to Use

Actual Technology Use
Studi ini bertujuan untuk memperoleh bukti empiris pengaruh kegunaan, kemudahan penggunaan, Computer Self-Efficacy (CSE), dan niat untuk menggunakan, terhadap penggunaan teknologi sesungguhnya sebagai isu terhadap kompleksitas Rumah Sakit (RS) sebagai organisasi kesehatan bidang jasa pelayanan. Desain penelitian menggunakan pendekatan kuantitatif dengan riset tipe kausalitas eksplanatorik. Data dianalisis menggunakan Path Analysis. Hasil: PU berpengaruh positif terhadap signifikan terhadap penggunakan ATU. PEOU berpengaruh positif signifikan terhadap BITU. PEOU berpengaruh positif terhadap ATU. Kesimpulan: BITU merupakan variabel yang memediasi pengaruh PU terhadap ATU. Temuan ini mengindikasikan bahwa adanya perilaku wajib dari penggunaan SIMRS secara aplikatif terhadap pengguna.

Article history: Received 2020-11-16; Revised 2020-12-28; Accepted 2021-02-25

C) 2021 JMMR. All rights reserved

\section{INTRODUCTION}

Technology Acceptance Model (TAM) is the most appropriate model in explaining user behavior in accepting, explaining, and predicting the usage of a systems (Chuttur, 2009). TAM can be modified by adding external factor, such as computer self-efficacy (CSE), as in this study focused on. This factor was studied because of one's belief could lead to certain behavior in using hospital management information system (SIMRS) (Bandura, 1977; Jogiyanto, 2008).

TAM is considered superior in explaining user behavior toward new information technology (IT) system as it is describing $40 \%$ of usage intention and behavior (Vekantesh, 2000). Thus, this study was proposed to be analyzed SIMRS acceptance in RSGM using TAM as the instrument. The study conducted in RSGM because there are tendencies of increasing customer demand for complete dental specialist service, service quality accordance to expectation, and anticipation to globalization. As one of dental hospital in Jakarta, RSGM Trisakti should do a service improvement and development. 
From unofficial pre-study observation in RSGM Trisakti, technology usage in decision making were considered not optimum. This mater caused by RSGM employees were dissatisfied with SIMRS performance, but no one conveyed any criticism or suggestions whilst technology can be perceived differently by one another. This led to no evaluation conducted to SIMRS improvement by the authority.

There were two terms to classify perception of interest in technology. Firstly, is perceived usefulness (PU), a trust in benefits and good results of technology. Secondly, perceived ease of use (PEOU), a trust in user friendly new technology system (Mulyana, 2005). An easy technology system is accouraging users to operate the systems.

Cronin et al (2000) stated that customer satisfaction are results from customer perception from accepted values. Perceived value is a benefit that is able to meet expectation so that it has an impact on the intention to reuse. Study from Wang (2008) suggested user satisfaction and perceived value are significantly positive for intended reuse the e-commerce.

Motivation to this study are better management system for hospitals using information system. Second, management information system changes from manual to computerized. This changing could cause adaptation conflict. Thirdly, there are condition in technology information systems implementation, reception or rejection based on perceived value and user friendly. This study intended so the systems could consider as alternative for hospitals to use SIMRS in RSGM Trisakti.

TAM measurement is observed by two basic variables, PU and PEOU. These variables representing application concept of TAM, from direct individual reception of technology. Davis (1985) described PU as "a degree to which a person believes using particular application system will improve its performance". As for PEOU he described as "a degree to which a person believes will be free from effort with particular system".

\section{Theory and Hypothesis Development}

TAM is used for explaining acceptance behavior to IT system or so-called IT. This model is one of the most influential models in explaining individual reception to IT (Jogiyanto, 2008). TAM was developed by Davis (1985) based on theory of reasoned action (TRA) model. TAM is a parsimony model, a simple but valid model, a better model than TRA and TPB as decision factor for computer acceptance and user behavior towards new technology.

In general, TAM has 5 main variables, which are PU, PEOU, attitude toward using technology, Behavioral Intention to Use (BITU), and ATU. It is explained user behavior in accepting, explaining, and predicting the usage of a systems.

\section{Variables Dependencies}

\section{Correlation between PU, PEOU, CSE, and BITU towards ATU in Hospital}

TAM theorizes individual intention to operate a system or technology is determined by two factors. First is PU towards ATU will increase performance, and secondly, PEOU IT. Studies related to prediction acceptances of IT getting lots of attention from companies to adopting and using it. One of the models used is TAM (Mohd, 2011). Nasution (2004) revealed that userr behavioral aspect is crucial in adopting IT because its interaction between user and computer device. Study from Wijayanti, et al (2009) indicate the higher personalization of CSE and trust, the easier information system being used by users. 
From multiple studies from Napitupulu et al (2017), Helia et al (2018), and Supriyanti et al (2017), we hypothesized as shown below:

H1: There is a significant influence between PU, PEOU, CSE, and BITU on ATU by employees at hospital.

\section{Effect of SIMRS PU towards hospital employees' BITU}

According to Davis (1989), PU interpreted as a degree to which a person believes using application system will improve its performance. Davis also mention that PU significantly correlate to BITU. From Ho et al (2019), PU PEOU, and satisfaction to technology acceptance affect in BITU over a system. Moreover, Alamanda (2015) in her study about perception influence over e-banking, showed that attitude was significantly influence BITU. Thus, based on those theories, we proposed this hypothesis:

$\mathrm{H} 2$ : There is a significant influence between SIMRS PU over BITU of employees in hospital

\section{Effect of SIMRS PU towards Hospital employees' ATU}

Davis (1989) and Adam (1992) defines usefulness for users is a degree to which a person believes using application system will improve its performance. Meanwhile, Thompson et al (1991) claimed that usefulness of IT is a benefit expected from IT users for accomplish their task. A study from Changay $\mathrm{R}$ et al (2017) claimed that Ubaya Learning Space (ULS), a system based on TAM, is directly influenced by PU and indirectly influenced by PEOU and technical support. Thus, technical support is correlated to ULS usage. Other research from Daerina SRF et al (2018) stated that there is positive and significant effect of PU towards BITU. Based on those theories, we hypothesized as stated below:

H3: There is effect of SIMRS PU towards ATU of employees in hospital.

\section{Effect of SIMRS PEOU towards BITU of Hospital employees}

Davis (1989) and defines PEOU as user's perception over easiness in adopting system. PEOU said to have direct effect to PU. PEOU significantly influencing BITU over PDA application in medical staff. Diop EB et al (2019) in their study about variable message sign (VMS) stated that PU is positively significant to PU and BITU. Furthermore, study from Aribowo T et al (2018) found that PEOU affecting BITU in SIMRS application at RSGM Muhammadiyah Yogyakarta. Thus, based on those theories, we assumed this hypothesis: H4: There is effect of SIMRS PEOU to BITU of hospital employees.

\section{Effect of SIMRS PEOU towards Hospital employees' ATU}

The crucial point for users in operating a system is the effort in it. PEOU described as a concept that has got attention in users' satisfaction over information system updates flow and e-commerce. Common and easy system application will increase person's intention to use (Davis, 1989). According to Adam et al (1992), users' intensity to use and interaction over system also showed effect on PEOU. Udayanti ED et al (2018), were study about analysis of interest on application TB eScoring with TAM approach. This study found that there is positive correlation of interest of use on TB eScoring application, with significant value less than 0.05. Ernawati D et al (2015) study found that the easier web-based academic system applied, the more beneficial and also effecting positive behavior over it. 
Meanwhile, study form Aji MB et al (2017) about SIMRS in RSIA Bhakti Persada Magetan in using TAM, has significant value over information system application. Based on theories above, we presumed this hypothesis:

H5: There is effect of SIMRS PEOU to ATU of Hospital employees.

\section{Effect of CSE towards Hospital employees' BITU}

TAM is a well (Park 2009), popular (Priyanka and Kumar, 2013), and also offering strong yet simple explanation (Davis 1989) theoretical tools to study about acceptance and utilize technology (Venkatesh, 2000). TAM relied on two perceptions, which are perceived application and usefulness of technology appliance for determined individual behavioral intention in using technology (Vekantesh, 2000). Intention described as actual behavioral predisposition (Ajzen, 1975) that affected by CSE (Vekantesh, 2000; Rose and Fogarty 2006; Park 2009; Yusof et al 2009; Abramson 2015).

Other research from Prasetyo MAW et al (2017), stated that self-efficacy as external factor had significant value to PU (66\%), PEOU (62.7\%), attention toward using $(62.5 \%)$, BITU (83.6\%), and ATU (82.3\%) on SIMPUS application. Handayani WPP and Harsono (2016) in TAM appliance in their studies, found that CSE is affecting technology's PEOU and PU. It also stated that user behavior towards technology is affecting their intention to use the technology. Hence, we hypothesized that:

H6: there is effect of CSE to BITU of hospital employees

\section{Effect of BITU towards ATU Hospital employees' ATU}

BITU is behavior tendencies for constantly using technology (Davis, 1989). It is influencing ATU and being influenced by PU. Study from Saputra and Misfariyan (2014) found that PEOU influenced PU, and PU influenced intention, last, intention influenced ATU. Darmaningtyas and Suardana (217) were stated similar result, that PU and PEOU positively significant value towards BITU among auditors' performance.

Supriyanti and Cholil (2017) found that CSE has effect to PU and PEOU towards SIMRS. Subjective norms influenced PU and PEOU towards SIMRS technology. System accessibility did not correlate to PU, buth has effect on PEOU of SIMRS technology. This study done at RS Ortopedi Prof. Dr. R. Soeharso Surakarta. Hence, according to theories above, we presumed hypothesis as stated below:

H7: There is effect of BITU to ATU of hospital employees

\section{Effect of CSE towards Hospital employees' AT}

CSE has similar dimension with self-efficacy by Bandura (1986) according to their similar individual beliefs on its capability to carry out behavior. The difference is at CSE limitation to computerized technology. This concept also fit to TAM's confidence concept over technology application impact. Therefore, CSE is proper to be tested as TAM's external factor. There is research that found out that CSE has positive value over computer usage, which means the higher CSE will rise computer usage (Achim \& Kassim, 2015). Other findings also stated about positive effects of CSE to PEOU (Saade \& Kira, 2009). The higher CSE, the easier technology application. CSE also has positive impact to higher performance output in technology application (Jahromi et al, 2016). 
Based on study from Widiasari and Achadiyah (2018), computer anxiety has negative impact to Small and Medium Enterprise (SME) doers in applying accountant IT. Whilst, CSE and PU have positive value to SME doers' interest on applying accountant IT. In research by Devi and Suartana (2014) concluded that CSE and trust have positive effect on $\mathrm{PU}$ and PEOU, in the other hand, personalization IT did not have any effect on both. Based on theories above, we hypothesized:

H8: There is effect of CSE to ATU of hospital employees.

\section{Research Model}

\section{RESEARCH METHOD}

The research model is shown in Figure 1.

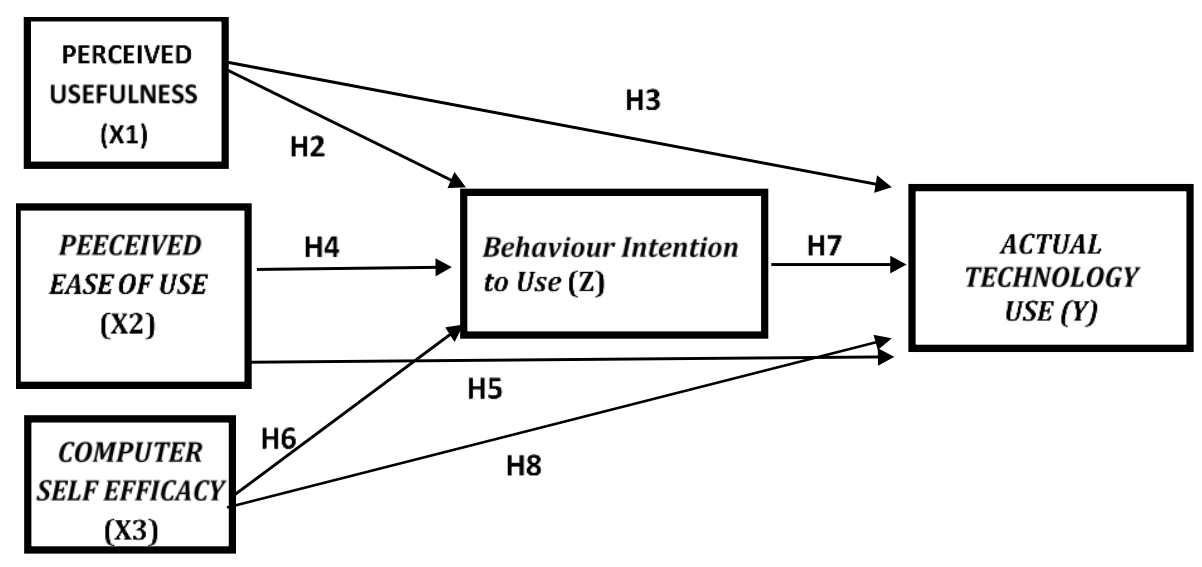

Figure 1. Research mode

This type of research is explanatory causality to explain the causal relationship simultaneously between variables (PU, PEOU, CSE, and BITU) against ATU. Data obtained by survey with primary data sources. This research data questionnaire includes opinions, attitudes, experiences, and characteristics of responders. This was a one-shot study and done by saturated sampling technique. There were 184 responders, in which were employees of RSGM Trisakti who conducted SIMRS. Unit of analysis is individual. Data analyzed by Path Analysis.

\section{Respondent Demography}

\section{RESULT AND DISCUSSION}

Research data obtained by surveys using questionnaires to 184 respondents. Of 184 questionnaires, we excluded 3 questionnaires that do not meet our criteria. Characteristics of respondents is the subject of this research are employees at RSGM Trisakti that using SIMRS. From demographic data, respondents' age was mostly at range 20 to 35 y.o and dominated by women who worked less than 5 years.

Validity and reliability test results. The reliability test done with Cronbach alpha with value range 0.681 to 0.948 . Value over 0.6 is reliable (Nunnally, 1978). The validity test done by Kaiser-Meyer-Olkin (KMO) resulted value ranging from 0.596 to 0.902. 
Hypothesis test simultaneously and partially shown in Table 1.

Table 1. Structural Equation Modelling Test (SEM)

\begin{tabular}{lccccc}
\multicolumn{1}{c}{ Variable } & Estimation & SE & CR & P & Note \\
\hline BITU $\leftarrow$ PU & .198 & .091 & 2.180 & .029 & H2 accepted \\
\hline BITU $\leftarrow$ PEOU & .166 & .083 & 2.016 & .044 & H4 accepted \\
\hline BITU $\leftarrow$ CSE & .204 & .086 & 2.385 & .017 & H6 accepted \\
\hline ATU $\leftarrow$ BITU & .397 & .073 & 4.830 & $* * *$ & H7 accepted \\
\hline ATU $\leftarrow$ CSE & .264 & .093 & 2.845 & .004 & H8 accepted \\
\hline ATU $\leftarrow$ PU & .171 & .084 & 2.033 & .042 & H3 accepted \\
\hline ATU $\leftarrow$ PEOU & .287 & .083 & 3.480. & .000 & H5 accepted \\
\hline \multirow{2}{*}{$\begin{array}{l}\text { Min was achieved } \\
\text { Chi-square }=.000 \text { (H1 accepted) }\end{array}$} & & Coeff of determination $\left(\mathrm{R}^{2}\right)$ & \\
& & BITU $=.676$ & & \\
\hline
\end{tabular}

Source: AMOS 21 output data, 2019

Intervening test. Structural equation modelling test done by Path Analysis result shown in Table 2. The Table 2. showed that ATU had an indirect effect to BITU (.000), which means BITU acted as mediating or intervening variable.

Table 2. Intervening Test between BITU, ATU, CSE, PEOU, PU, and BITU

\begin{tabular}{lllllllll}
\multirow{2}{*}{ Variable } & \multicolumn{2}{c}{ CSE } & \multicolumn{2}{c}{ PEOU } & \multicolumn{2}{c}{ PU } & \multicolumn{2}{c}{ BITU } \\
\cline { 2 - 9 } & $\begin{array}{l}\text { Direct } \\
\text { effect }\end{array}$ & $\begin{array}{l}\text { Indirect } \\
\text { effect }\end{array}$ & $\begin{array}{l}\text { Direct } \\
\text { effect }\end{array}$ & $\begin{array}{l}\text { Indirect } \\
\text { effect }\end{array}$ & $\begin{array}{l}\text { Direct } \\
\text { effect }\end{array}$ & $\begin{array}{l}\text { Indirect } \\
\text { effect }\end{array}$ & $\begin{array}{l}\text { Direct } \\
\text { effect }\end{array}$ & $\begin{array}{l}\text { Indirect } \\
\text { effect }\end{array}$ \\
\hline BITU & .297 & .000 & .221 & .000 & .194 & .000 & .000 & .000 \\
ATU & .564 & .682 & .187 & .057 & .000 & .050 & .259 & .000 \\
\hline
\end{tabular}

Source: AMOS 21 output data, 2019

\section{Discussion}

Hypothesis 1. PU, PEOU, CSE, and BITU effects on ATU in hospital. This hypothesis is accepted because PU, PEOU, CSE, and BITU has significant effect on ATU. This result showed that RSGM Trisakti employees exhibit PU, PEOU, CSE, and BITU in normal behavior. Responders indicated that SIMRS were easy to perform, they could use the system, and intended to use and operate it. This result supported by TAM theory that individual intention to operate a system or technology is determined by two factors. First is PU towards ATU will increase performance, and secondly, PEOU is level of believes that technology usage will ease in completing the job (Vekantesh and Davis, 2000).

TAM believe that information system application could increase individual or organization performance and also ease users to complete their task (Dasgupta, 2002). World business development caused a demanding study pointing to IT usage. Researches about predicting factors received a lot attention because many companies adopted and used IT system and TAM as a promising model to exploring it (Mohd, 2011).

These results are also supported by study from Nasution (2004) and Adhikara (2014, 2016, 2017) described behavior aspect in adopting IT is necessary because user and computer device interaction is a result from perception, behavior, and affection as personalized behavioral aspect. Wijayanti et al (2009) stated in her research, that subjective norms, CSE, and trust make users to experience usefulness and ease of use. 
Based on research result from Napitupulu et al (2017), all indicators of TAM are valid and represented each of TAM dimension. Another research from Helia et al (2018) stated that TAM could be used for evaluating SIMRS. Supriayanti and Cholil (2017) also state that CSE influenced on PU and PEOU towards SIMRS technology. Subjective norms had effect on PU and PEOU towards technology application in SIMRS. System accessibility did not have effect on PU but influencing PEOU of SIMRS technology. PEOU influence PU in SIMRS. Both PU and PEOU did not have any effect on BITU in SIMRS application. Behavior in using technology had effect on ATU of SIMRS. Meanwhile, intention to use technology has effect on BITU in SIMRS application at RS Ortopedi Prof. Dr. R. Soeharso Surakarta.

Hypothesis 2. PU effects of SIMRS towards BITU of hospital employees. This hypothesis is accepted because this study found out that PU had significant effect on BITU. This finding explained that increased perceived usefulness will increase intention to use SIMRS. We concluded that responders found that using SIMRS would made them finishing task faster, boosting performance, increasing productivity and efficiency, and also making easier to finishing task. Thus, BITU are affected by these results.

This result was corresponding with Davis theory (1989) in which PU interpreted as a degree to which a person believes will be free from effort with particular system. Davis also found out that users' perception over PU is correlate to BITU.

Another in line study from Ho et al (2019) and Adhikara (2016) explained that PU and PEOU that influence behavioral intention to apply the system. Alamanda (2015) in her study stated that PU significantly influencing behavioral in using internet banking.

Hypothesis 3. PU effects of SIMRS towards ATU of hospital employees. This hypothesis is also accepted because PU is significantly positive in influencing ATU. This is mean, ATU will increase if PU of SIMRS reception increased. We concluded that responders found that using SIMRS would made them finishing task faster, boosting performance, increasing productivity and efficiency, and also making easier to finishing task. This result referred to higher scale index, SIMRS usage could make a better change. Whereas on a moderate scale, which is in accordance with everyday practice, ease to use and learn, and is given the opportunity to innovate before using SIMRS and feels that SIMRS can provide very clear benefits.

These results supported the theory of Davis (1989) which stated that the definition of user benefits is the degree to which a person believes that using particular system will improve working performance. Meanwhile, according to Thomson et al (1991), IT benefits are expected by IT users in carry out their duties.

Other research from Changay et al (2017) claimed that Ubaya Learning Space (ULS), a system based on TAM, is directly influenced by PU and indirectly influenced by PEOU and technical support. Thus, technical support is correlated to ULS usage. Daerina et al (2018) regarding SIMRS at Kaisat Regional Hospital, it was found that there was no positive and significant influence of PU on behavioral tendencies. It was positive and significant attitude towards behavioral tendencies and there is no mediating effect by attitude.

Hypothesis 4. PEOU effects of SIMRS towards BITU of hospital employees. This hypothesis is accepted, because the results of this study of PEOU has a significant positive effect on BITU. This means that if PEOU increases, intention to use SIMRS will increase as well. 
The support for PEOU and BITU stated that RSGM employees found it easy to learn and operate SIMRS and overall felt SIMRS was easy to use. Moderate scale was found in statement that SIMRS is easy and meet their expectations. This statement affects BITU on high scale index, that RSGM employees attempt and willing to continue SIMRS in the future. Meanwhile, at moderate scale statement, is plan and intend to use SIMRS in the future. These results support Davis' theory (1989) that defines PEOU as a users' perception of easiness in adopting a system. PEOU is said to have a direct impact on PU. Yi, Jackson, park, and Probst in their research stated that PU and PEOU have a significant influence on BITU regarding PDA technology usage among health workers.

These results support research from Diop et al (2019) regarding adoption of variable message signs (VMS) that PEOU significantly positive in affecting PU and intended to use VMS. In addition, research by Aribowo et al (2018) and Adhikara (2016, 2014, 2017) showed that PU and PEOU has a positive effect on BITU.

Hypothesis 5. PEOU effects of SIMRS towards ATU of hospital employees. This hypothesis is accepted, because PEOU significantly positive in affecting ATU. This means if PEOU on SIMRS increases, then ATU will increase as well. The results supported PEOU and ATU that stated RSGM Trisakti employees found out that SIMRS was easy to learn and operate and as overall was easy to use. So, these results will affect ATU of SIMRS to make a better change in accordance with practical usage, easy to use and learn, and gave opportunity to innovate before using SIMRS, and feels that SIMRS can provide very clear benefits.

These results support Davis' theory (1989) which stated that users' effort is crucial in operating a system. PEOU is a concept that has received attention in users' satisfaction in the flow of IT and e-commerce research. An easy to use system will increase one's intention to use it. These results were also support a research by Aji MB (2017). In using TAM, quality system variable simultaneously has significant effect on information system application.

Research by Udayanti et al (2018) showed that PU has a significantly positive correlation to interest in use. In addition, the easiness variable also has a positive relationship with interest in using TB eScoring application. Research by Ernawati and Lutfi (2015) stated that application of WEB-based academic service information system is easier for user to operate it. It will provide significant benefits, affect attitudes, and influence actual behavior in using information system.

Hypothesis 6. CSE effects on BITU of hospital employees. This hypothesis is also accepted because CSE significantly influence BITU. This means that increasing CSE will increase the BITU of SIMRS. Ability to use SIMRS affects their intention in using SIMRS. This result is also supported CSE index statement that employees of RSGM Trisakti were able to use SIMRS without any assistance by believing that they could operate and understand SIMRS very well.

There is high scale index statement on BITU, that employees of RSGM Trisakti are putting effort and will continue to use SIMRS in the future. On moderate scale statement, plan to use SIMRS and intending to use SIMRS in the future. These results were also support Vekantesh theory (2000), TAM is a good theoretical tool (Park, 2009), popular (Priyanka and Kumar,2013), and offers strong and simple explanation (Davis, 1989) for study acceptance and technology usage. TAM shows two specific beliefs, PEOU, and PU to determine one's BITU in using technology (Vekantesh, 2000). Intention is a predisposition to actual behavior 
(Ajzen, 1975) that influenced by CSE (Vekantesh, 2000; Rose and Fogarty, 2006; Park, 2009; Yusof et al, 2009; Abramson, 2015).

Prasetyo MAW et al (2017), stated that self-efficacy as external factor had significant value to PU (66\%), PEOU (62.7\%), attention toward using (62.5\%), BITU (83.6\%), and ATU (82.3\%) on SIMPUS application. Handayani WPP and Harsono (2016) in TAM appliance in their studies, found that CSE is affecting technology's PEOU and PU. It also stated that user behavior towards technology is affecting their intention to use the technology. But there is a different result to Prasetyo MAW et al (2017) that stated external self-efficacy variable affects BITU. In another research stated, CSE indirectly affects BITU.

Hypothesis 7. BITU effects on ATU of hospital employees. This hypothesis is accepted because in this study concluded, BITU positively significant to ATU. This means that increasing BITU, will increase implementation of ATU as well. This results support BITU and ATU. RSGM Trisakti employees always try to use, plan, and intend to use SIMRS in the future. So these results will affect ATU that SIMRS usage could make a better change according to, daily practice, easiness in learn and use, and are given opportunity to innovate using SIMRS and also provide very obvious advantage. These results support Davis' theory (1989) that stated BITU is a behavioral tendency to continue using a technology. BITU has an influence on ATU and influenced by attitude and PU.

It supported research by Saputra and Misfariyan (2014) regarding PEOU that affects PU, PU affects intentions, and intention affects ATU. Subjective norms influence PU and PEOU in SIMRS. System accessibility does not affect PU but affect PEOU in SIMRS. PEOU influences PU regarding SIMRS. PU and PEOU have no effect on attitudes to using technology in SIMRS. The attitude in using technology affects the intention to use in the SIMRS, while intention to use technology affects BITU in SIMRS at Prof. Dr. R. Soeharso hospital, Surakarta.

Hypothesis 8. CSE effects on ATU of hospital employees. This hypothesis is accepted because CSE negatively significant influence of ATU ( $p=0.535)$. This means in contrary, if CSE increase, implementation of ATU of SIMRS will decrease.

There are supporting results shown that the ability in using SIMRS is related to ATU of SIMRS. This was boosted by employees that are able to perform SIMRS without assistance from anyone. They believe they could operate and understand SIMRS well. Meanwhile, on ATU, there is high index statement that the use of SIMRS can make changes for better, while on moderate scale, stated in accordance with everyday practice, PEOU and learn is given the opportunity to innovate before using SIMRS, and felt SIMRS could provide very clear advantage.

According to Bandura's theory (1986), CSE has the same dimension as self-efficacy because both are individual's beliefs on their ability to carry out a behavior, but CSE is limited to the use on computer technology. This concept also appropriate when juxtaposed with concept in TAM, because it can affect technology usage. There is research that found out CSE has a positive effect on computer use, which means the higher CSE, the higher the computer use (Achim and Kassim, 2015). Other findings also support the positive influence of CSE on PEOU (Saade and Kira, 2019). The higher CSE, the easier to operate the technology. CSE has a positive effect on one's performance in using technology, thereby increasing one's performance when using technology (Jahromi et al, 2016). 
Based on research results conducted by Widiasari and Achadiyah (2018), computer anxiety has a negative effect on the interest of SME doers in applying accounting IT. Because, the more hesitant and the lower anticipation over certain system, will further lowered interest. Meanwhile, CSE and PU have positive effect on SME doers in applying accounting IT. Research by Devi and Suartana (2014) reported that CSE and trust have a positive and significant effect on PU and PEOU, while personalization does not affect on both. On contrary, Widiasari and Achadiyah (2018), CSE has a positive effect on SME doers' interest in applying accounting IT.

Research Findings. Hospital employees whose using SIMRS have a high intention to use SIMRS because it is useful, make work faster, and easier by increasing productivity, performance, and effectiveness in implementing SIMRS. This shows that in order to help improve the intention to keep using the technology, we need mandatory, trial, workshop, socialization, and participation between SIMRS users and operators. It is also necessary to increase the performance of SIMRS to be more user friendly.

\section{CONCLUSION}

PU, PEOU, CSE, and BITU have a positive effect on ATU, because employees feel they can complete tasks faster, more effective, more productive, and easier by using SIMRS. BITU has a positive effect on ATU, because the employees' intention by keep on try using SIMRS affects SIMRS usage that entrusted to change for the better RSGM Trisakti. CSE has a significant effect on ATU, because its ability to use SIMRS is related to SIMRS application that occurs in field. Thus, these findings suggested that there is mandatory behavior toward users to apply SIMRS.

Implication are from this research results, it is necessary to take corrective steps in management of RSGM Trisakti. First, theoretically the result of this study support TAM theory about usefulness of IT in hospital operational activities. This theory is open to behaviors that support TAM, thus new variables need to be developed in the future, including innovation system, decision, diffusion, and knowledge management.

Second, in practical terms, this study result could have positive implications for RSGM Trisakti management to consider usability aspects, ease of system operation, and innovation in actual use to design the system before running it. Socializing to related units (medical, nursing, support, management, and administration) regarding needs in SIMRS where involving verifiers in information application. Integrating system within each unit in order to produce supportive decision by hospital director; customize SIMRS according to particular demand in each unit.

Based on results above, we recommend validation to be done by particular section to provide output and outcome review of products; Evaluating SIMRS according to daily bases of each hospital unit or division to ease the employees during performing SIMRS; Socialize and evaluate every employees regarding SIMRS usage, to maximize IT usage and also grow employees' intention over simultaneously using SIMRS in the future; increasing collaboration between SIMRS users by involving them to design, test, implement, and development of system, so that users could feel their role in determining successive or failing system. 


\section{ACKNOWLEDGMENT}

I would say thank you to Dr. MF. Arrozi, SE, M.Sc., Akt., CAand Dr. Rokiah Kusumapradja, SKM, MHA, for their permission and supervision so that this research to be very well delivered.

\section{REFERENCE}

Adhikara, M. (2016). Revisi Keyakinan atas Sinyal Informasi Akuntansi. Jurnal Akuntansi dan Auditing Indonesia.

Adhikara, M. (2017). Disjunction Behaviour in the Indonesia Stock Exchange (IDX),. International Journal of Applied Business and Economic Research.

Adhikara, M., \& Maslichah, N. (2016). The Benefits of Accounting Information on the Intention of Stocks Selections in Indonesia Stock Exchange (IDX). The Indonesian Journal of Accounting Resarch. https://doi.org/10.33312/ijar.370

Adhikara, M., \& ND, M. (2014). Qualitative Characteristics of Accounting Information in the Belief Revision of the Users for the Securities Prospects in Indonesia Stock Exchange (IDX). Journal of Economics, Business, EF Accountancy Ventura, 91-104. https://doi.org/10.14414/jebav.v17i1.269

Adhikara, M., \& ND, M. (2016). Mimetic Action Performed by Individual Investors a Indonesia Stock Exchange (IDX). International Journal of Applied Business and Economic Research.

Aribowo, T., Pribadi, F., \& Dewanto, I. (2017). Evaluasi Implementasi Sistem Informasi Rumah Sakit Gigi dan Mulut Universitas Muhammadiyah Yogyakarta Ditinjau dari Technology Acceptance Model. Unpublished Disertation. UMY.

Changay, R., Wijaya, S., \& Ayu, K. (2017). Faktor-faktor yang Mempengaruhi Penerimaan Ubaya Learning Space Berdasarkan Technology Acceptance Model. Jurnal Ilmiah Mahasiswa Universitas Surabaya.

Daerina, S., Mursityo, Y., \& Rokhmawati, R. (2018). Evaluasi Peranan Persepsi Kegunaan dan Sikap Terhadap Penerimaan SIstem Informasi Manajemen Rumah Sakit (HMIS) di RUmah Sakit Daerah Kalisat. Jurnal Pengembangan Teknologi Informasi dan Ilmu Komputer.

Darmaningtyas, I., \& Suardana, K. (2017). Pengaruh Technology Acceptance (TAM) dalam Penggunaan SOftware oleh Auditor yang Berimplikasi pada Kinerja Auditor. e-Jurnal Akuntansi Universitas Udayana.

Diop, E., Zhao, S., \& Duy, T. (2019). An Extension of the Technology Acceptance Model for Understanding Travelers; Adoption of Variable Message Signs. PLoS ONE. https://doi.org/10.1371/journal.pone.0216007 
Ernawati, D., \& Lutfi, H. (2015). Faktor-Faktor-yang Mempengaruhi Penerapan Sistem INformasi Layanan Akademik Berbasis Web. Unpublished Disertation. IKPIA Perbanas.

Handayani, W., \& Harsono, M. (2016). Aplikasi Technology Acceptance Model (TAM) pada Komputerisasi Kegiatan Pertanahan. Jurnal Economia. https://doi.org/10.21831/economia.v12i1.8415

Helia, V., Asri, V., \& Miranda, S. (2018). Modified Technology Model for Hospital Information System Evaluation - a Case Study. MATEC Web of Conference. https://doi.org/10.1051/matecconf/201815401101

Ho, K., Ho, C., \& Chung, M. (2019). Theoretical Integration of User Satisfaction and Technology Acceptance of the Nursing Process Information System. PLoS ONE. https://doi.org/10.1371/journal.pone.0217622

Napitupulu, D., \& Kadar, J. J. (2017). Validity Testing of Technology Acceptance Model Based on Factor Analysis Approach. Indonensian Journal of Electrical Engineering and Computer Science. https://doi.org/10.11591/ijeecs.v5.i3.pp697-704

Siregar, J., Puspokusumo, R., \& Rahayu, A. (2017). Analysis of Affecting Factors Technology Acceptance Model in the Application of Knowledge Management for Small Medium Enterprises in Industry Creative. Procedia Computer Science, 116. https://doi.org/10.1016/j.procs.2017.10.075

Supriyanti, \& Cholil, M. (2017). Aplikasi Technology Acceptance Model (TAM) pada Sistem Informasi Manajemen Rumah Sakit. Jurnal Bisnis dan Manajemen. https://doi.org/10.23917/dayasaing.v18i1.3817

Udayanti, E., \& Nugroho, F. (2018). Analisa Minat Penggunaan Aplikasi TB eScoring dengan Pendekatan Technology Acceptance Model (TAM). Edu Komputika Journal.

Widyasari, R., \& Achadiyah, B. (2018). Computer Anxiety, Computer Self-Efficacy and Perceived Usefulness oleh Pelaku UMKM. Jurnal Akuntansi Aktual. https://doi.org/10.17977/um004v5i32019p203 